\title{
New Perspectives in Teaching Writing Skill
}

\section{Communicatively \\ Israa Rashed Mahdi Al-Kubaisy \\ Gifted Students' School\Al-Anbar \\ Iraq1902@yahoo.com}

Submission: 160 at17 $\backslash 4 \backslash 2016$

Abdullah: 352 at $25 \backslash 5 \backslash 2016$

\section{Abstract:}

This paper belongs to applied linguistic study of teaching writing in English language. It also shows the ways and approaches that teachers or instructors use to facilitate the materials to their students. This paper studies the role played by teaching writing in English. In terms of skills, producing a coherent, fluent, extended piece of writing is probably the most difficult thing there is to do in language. It is something most native speakers never master, particularly for those who go on to university and study in a language that is not their own. This paper focuses on approaches and the ways that facilitate teaching writing skill communicatively. The aim of teaching writing is to develop the ability of students in writing and grasp the vocabulary and use it in correct position. Writing is creative skill and technique to learn language well throughout spelling, vocabulary, dictation, punctuation, composition and so on.

Key Words: writing, skill, communicatively, approach and teaching.

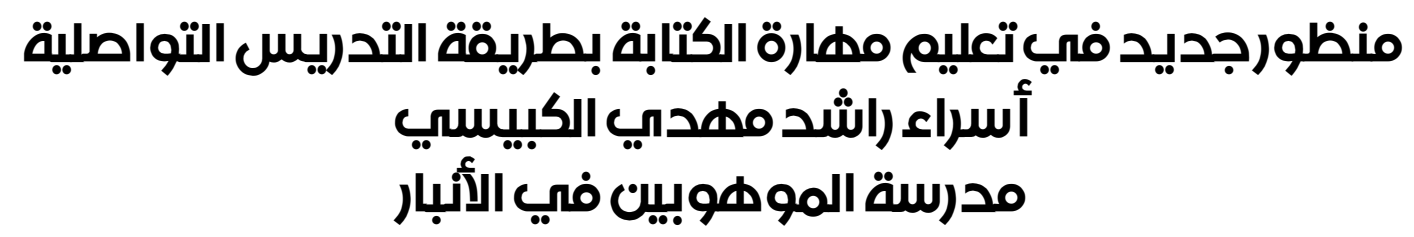

Iraq1902@yahoo.com

الملخص:

تعود هذه الدراسة إلى دراسة اللغة التطبيقة للتدريس مهارة الكتابة باللغة الإنجليزية. هذه الدراسة أيضا توضح الطرق والأساليب التي يستخدمها المعلمين أو المدربين لتسهيل المادة لطلابهم. هذه الدراسة تدرس الدور الذي لعبته الإنه

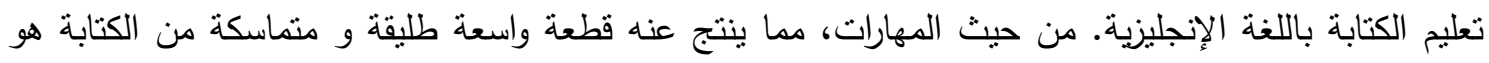
ربما أصعب شيء هناك هو أن تفعله في اللغة. أكثر المتحدثين الأصليين أبدا لا يتقون الكتابة، ولاسيما بالنسبة لأولئك الذين يذهبون إلى الجامعة والدراسة في اللغة التي هي ليست لغة الام لديهم. وتركز هذه الدراسة قي النهج

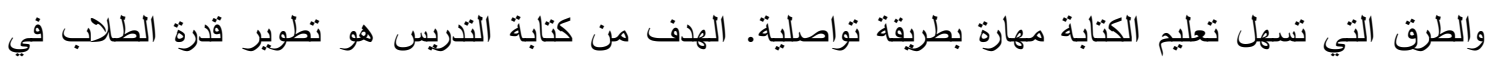

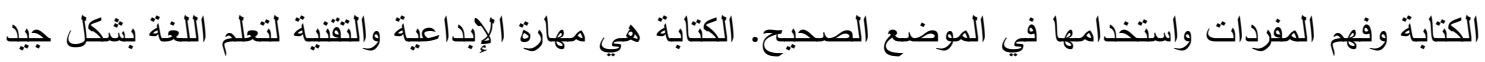
في جميع أنحاء الهجاء والمفردات، والإملاء وعلامات الترقيم وتكوين جمل ومقاطع انشائية.

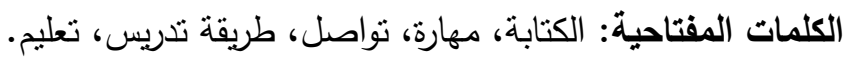




\section{Introduction:}

This paper sheds light on how to teach writing communicatively . Also , it consists of four parts : the first one gives an introduction, the second is about the definition of writing, the third is about aims of teaching writing, the forth is about approaches to student writing, the fifth is about how to teach writing communicatively, and the sixth gives a conclusion.

Concern with the teaching of writing goes back thousands of years.

Up until the early twentieth century, writing instruction was based on a somewhat rigid set of assumptions: good writing was done from a set of rules and principles, the teacher's duty was to relate these rules, and students then wrote in response to selected written texts, following the rules of good writing. (David Nunan, 2003: 88).

After that the teaching philosophy grew directly out of the audio lingual method students were taught incrementally, error was prevented and accuracy was expected to arise out of practice with structure. In the early 1980, a teacher became more aware of current practices in native English speaker composition, there was a shift from strictly controlled writing to guided writing: writing was limited to structuring sentences, often in direct answers to questions, or by combining sentences the result of which looked like a short piece of discourse (Ronald Carter and David Nunan, 2001: 28).

The slow but significant shift from language based writing classrooms to the study of composition techniques and strategies began with researchers' recognition of the newly developing field of native English speaker composition and teacher's realization of the needs of English L2 students, in the academic environment with the gradual acceptance error as productive and developmental rather than substandard and deviant, grammatical accuracy became secondary to communication (ibid).

After 1960s, that a broader understanding of writing and the teaching of writing began to take hold in classrooms. Writing instruction began to include the entire process of writing, invention, drafting, feedback, and revision and not just the product (Nunan, 2003: 89).

\section{Definition of Teaching Writing}

Writing is the process or result of recording language in the form of conventionalized visible marks or graphic signs on a surface. Materials, tools and techniques vary in time and place (stone, paper, chisel, pen, printing, etc.), but several distinct stages or types of writing systems may be distinguished. The forerunners of written signs were pictorial devices to describe or record-events in messages (Pictograms). The first full writing systems consisted of logograms representing words, e.g. Egyptian hieroglyphs or Chinese characters, further stage was reached by abstract signs representing syllables, e.g. Mesopotamian cuneiform, west semitic syllabary, Japanese Kana; finally in alphabetic scripts the individual sounds 
of human speech are represented by phonetic, linguistic skill, literacy (Hartmann, 1972: 258)

Writing can refer to either a process or a result while we are actively engaged in the process, we are said to be writing and when we have finished, the product (our composition, or text) is called writing or (piece of writing). Writing can refer to either an everyday or a professional activity. All literate people, by definition, can write, but only a tiny minority are writers i.e. authors. (David Crystal, 2003: 257

Writing is both a physical and a mental act. At the most basic level, writing is the physical act of committing words or ideas to some medium, whether it is hieroglyphics inked on to parchment or an e-mail message typed into a computer. Writing is the mental work of inventing ideas, thinking about how to express them, and organizing them into statements and paragraphs that will be clear to a reader. It is both a process and a product. The writer imagines, organizes, drafts, reads, and rereads.

This process writing is often cyclical, and sometimes disorderly, ultimated, what the audience sees, whether it is an instructor or a wider audience is a product an essay, letter, story, or research report. (David Nunan, 2003: 88 ).

\section{Aims of Teaching Writing}

Writing purpose is both to express and impress. Writers typically serve two masters themselves, and their own desires to express an idea or feeling, and readers or audience, who need to have ideas. ((David Nunan, 2003: 88).

Writing helps to solidify the students grasp of vocabulary and structure and complements the other skills, appropriacy can be developed only through writing. Also, the goal of writing is to develop the students ability to write up to the point at which written homework can be given. The goal in writing is two fold. Psychological students are more impressed by exercises that are to be written and handed in than by those that are to be learned. Realistically the teacher knows that writing homework exercises and other written activities help the students to acquire the vocabulary and the grammar of the lesson (Venkates Waran: 1995, 105).

Practically the students' minimum contact with the language in the classroom must be expanded as much as possible. The overall objective then will be to help the learners express their ideas in written form (ibid).

\section{Approaches to Student Writing}

\subsection{Process and Product}

In the teaching of writing we can either focus on the product of that writing or on the writing process itself when concentrating on the product, we are only interested in the aim of a task and in the end product. As we shall see below, a consideration of written genre has a lot in common with a product approach to writing i.e. an approach which values the 
construction of the end product as the main thing to be focused on (Jeremy Harmer, 2009: 325).

\subsection{Creative Writing}

The term creative writing suggests imaginative tasks such as writing poetry, stories, plays such activities have a number of features to recommend them. Chief among these is that the end result is often felt to be some kind of achievement and that most people feel pride in their work and want it to be read. This sense of achievement is significantly more marked for creative writing than for other more standard written products. Creative writing is a journey of self-discovery and self-discovery promotes effective learning. When teachers setup imaginative writing tasks so that their students are thoroughly engaged, those students frequently strive harder than usual to produce a greater variety of correct and appropriate language than they might for more routine assignments(ibid).

\subsection{Writing for Learning and Writing for Writing}

Writing for learning is the kind of writing we do to help students learn language or test them on that language. Thus, if we say write three sentences using the 'going to' future, our aim is not to train students to write, but rather to help them remember the going to future. (Jeremy Harmer, 2009: 325)

\section{How to Teach Writing Communicatively \\ 5.1 Teaching of Spelling}

In the teaching of spelling to beginners, two major considerations should be attended to. The first is that the major purpose of training in spelling is to enable the learner to master subconsciously the major spelling patterns of English. Such an accomplishment should enable the learner to spell correctly words that he has never seen before. He will be able to do that relying on "analogy". If, for example, he has mastered the pattern at consonant $+\mathrm{e}=/ \mathrm{ei} /$ as in plate, make, etc, he will be able to spell correctly words like, fade, etc, even though he has never seen such words before. The moral in all this is to emphasize the fact that training in spelling should concentrate on the major patterns first(Hamash,1980: 155).

The second important consideration in the teaching of spelling is that the material used (words, sentences) should be drawn exclusively from the language used in the programme. Pupils should not be made to spell words they have never studied before (ibid).

\subsection{Teaching Punctuation}

Punctuation is a type of writing device that can be taught through both spelling and composition.

The teaching of word punctuation starts as soon as teaching spelling begins ward-punctuation and end-punctuation marks are easily taught in sentence, i.e., simple statements, commands and simple questions, such as:

"You're a boy. She's a girl". 
"Sit down. Stand up".

\section{"Is this a pen? Is that a pencil?"}

The teaching of the other punctuation marks could be practiced through the teaching of paragraphs and letter writing. The pupils' attention should be drawn to the use of certain punctuation marks, when teaching writing. Enough examples should be given, and the student's achievement should be checked by a short test at regular intervals. (Hamash, 1980: 164)

The English syllabus includes punctuation marks such as full-stop, coma, question mark and inverted commas ..... etc. The teacher of English should take all precaution to include them in his blackboard writing without fail, for example he uses columns for these marks of punctuation.

\begin{tabular}{|c|l|l|l|l|}
\hline This & Is & A & $\begin{array}{c}\text { Table } \\
\text { cat } \\
\text { door }\end{array}$ & \\
\hline
\end{tabular}

This will enable the students to use the correct mark of punctuation in their writing of sentences. (Venugopal,2003: 71)

\subsection{Teaching of Vocabulary}

Vocabulary items also called lexical items are content words such as: 1 . nouns, verbs, adverbs and adjectives. Or 2. names, of things we see, use, eat, drink, play with etc. 3. Those of birds, animals, professions. 4. Those of relations, actions. 5. Those that describe persons, things, actions are very important. 6 . These and their inflections and derivatives where possible are to be taught as words by inflections such as book $\longrightarrow$ books, while derivatives are happy happily.

The method of teaching words depends on the kind of words. In pedagogy, words are divided into two categories (a) words for active use by students in recognition. The teacher may decide which words are to be taught for active use and which for passive recognition. The different techniques of teaching words are explained in the following paragraphs.

\section{Situations /Gestures/ mimes}

The new word is presented orally through situations or gestures or mimes. Real objects, models, specimens, pictures and other suitable teaching aids can be used to help students to follow the situational meaning of the word.

\section{Giving definitions /Synonyms/ Antonyms/ Equivalents in the mother tongue.}

a) Words like waiter, pilot, are taught by using suitable definitions.

b) Words like rogue, sad, phrases / idioms can be taught through synonyms. The teacher should use a good dictionary to arrive at the right synonyms which are known to the students.

c) Words such as artificial, refuse, depart can be taught using antonyms which are known to the students. 
d) Words which cannot be taught by any of the techniques mentioned so for can be translated into the mother tongue and are equivalent in English may be given.

\section{Using pictures}

Most words in the syllabus can easily be taught using pictures.

\section{Explaining the words at the time of reading the passage.}

These words are the least important ones. The explanation should enable the students to understand their meaning in that particular context. If a person has been described as a 'louse' (meaning a worthless fellow), the explanation can start from the insect louse that lives in hair and arrive at the figurative meaning.

\section{Getting students to look up words in a dictionary at home / school.}

This technique is meant more far helping students to develop the reference skills than for finding the word meaning. They may be given a set of words (found in the passage to be read by them the next day) for this kind of reference work.

\section{Taking groups of words together}

Bicycle-scooter, motor-cycle, car, van, bus can be taught together. Another set is village town, city are some such groups. (Venugopal, 2003: 122)

\subsection{The Teaching of Dictation}

Recombination dictation a mixture of recombination and reproduction consists of rearrangement of dialogue sentences, or narratives constructed from the conversational material or from pattern sentences used in classroom oral practice, since dictation involves ability to recognize these re combinations aurally and retain them, as well as reproduce them graphically, such dictations must be constructed carefully so that problems of aural recognition do not coincide with problems of graphic representation. At this stage, work to be written from dictation should not contain distinctly new elements. Elements recombined and learned thoroughly, studied in graphic from, and used in some kind of writing practice, with, at most, the addition of some simple analogic variants of these.

The dictation with them serve as a form of review, the possibility of error will be reduced, and the students will be encouraged by their progress, the teacher should dictate at a normal speed of utterance, not distorting the phrases and the follow of speech in any way. Segments dictated should consist of meaningful word groups. Each phrase should be repeated clearly only once before students are expected to retain what they have comprehended aurally long enough to write it accurately, students should be encouraged to repeat a loud to themselves what they have heard before attempting to write it from dictation, and then to repeat it again as they write it. 
This oral of repetition helps them to rotation what they have heard long enough for them to write the complete phrase. After they have had time to write the whole word or phrase, the same segment should be repeated to allow students an opportunity to check what they have written and correct any inaccuracies. The dictation practice will then be reinforcing practice in listening comprehension as well as providing practice in accurate writing (Rivers, 1981: 301).

\subsection{Teaching of Composition}

Words play an increasing part and for most adult learners they are the major, though not the only, means of communication. Therefore, good writing is not likely to develop in the absence of a fair reserve of vocabulary.

Writing should, then, be connected with the growth of the use of language in speech and reading. Learners should be encouraged to notice more complex forms of expression in their reading before they start writing.

There are three stages in the process of writing composition:

1. Forming the idea one is to communicate.

2. Molding that idea into a pattern.

3. Transforming that pattern of ideas into connected words.

Composition writing is the peak of writing (Hamash, 1980: 164).

\subsubsection{Teaching Guided Composition}

Though words are essential in communication an idea or a thought is to be formulated in the mind of the writer at first. The amount of knowledge and spelling, ability to construct complex sentences and the use of skills in hand writing, Though vitally important for writing, will never take the place of having something to say and knowing how to say it(Hamash, 1980: 164).

The steps of guided composition start by giving students a number of questions. Students are required to make a paragraph out of these questions. (Venkates Waran, 1995: 113). The first step for a teacher is to follow then is to help the learners to form a thought that he can express through the vocabulary he possesses and the language structure he has mastered. Having acquired a wealth of words and a good reserve of structure and spelling patterns, the pupils should be enabled to proceed immediately to write sentences. Each sentence should express a single idea. Other connected sentences should follow later. The pupils should be trained to express the same meaning in as many ways as possible, to practice a variety of ways of writing. As a final stage, the teacher should help and guide pupils to join these sentences in a paragraph expressing a whole idea. (Hamash, 1980: 164)

\subsubsection{Teaching Free Composition}

Free composition involves individual selection of vocabulary and structure for the expression of personal meaning. Students will be trying to 
express themselves more concisely, more descriptively, less casually. This will severely test their control of structure and their precise understanding of lexical meaning. The composition stage provides teacher and student with opportunity to identify persisting areas of misunderstanding on an individual basis, so that remedial practice may be undertaken where necessary.

The transition from guided writing into free composition has to be gradual. Student will be asked merely to describe, narrate, explain or summarize. As they become more accustomed to expressing themselves within voluntarily accepted restrictions, they will be asked to comment on or develop ideas beyond those in the material read. Only when their skills in writing comprehensibly and accurately is established may they be expected to imitate the style of great writers, write literary criticism, or discuss ideas of philosophical or sociological level. Precise description of persons, places, and things provide excellent training in exact expression, as do instructions and arrangements.

This composition may consist of a summary of the content with a personal commentary, or the narration of some aspect of the story assigned previously by the teacher. Students with imagination and a flair for invention will be encouraged to use their originality in selecting their own approach. (Revers, 1981: 303-305)

Students are required to make a free paragraph on a given title.

Ex: Write a paragraph on ...

A number of a paragraph makes a composition writing skills starts with the control of the alphabetic system. It includes the arrangement of 1. Spelling words.

2. Putting the words in the right word order.

3. Making of paragraph (Venkates Waran, 1995: 112)

\section{Conclusion:}

Throughout this study many remarkable conclusions have been found: they are:

1. This study is an attempt to investigate the applied linguistic levels and approaches concerning teaching writing skill in English language.

2. Vocabulary should be carefully chosen in writing sentence, paragraph and so on because the construct the overall message that the writer wants to receive and be comprehensive by the reader.

3. Writing is a basic communication skill and a unique asset in the process of learning a second language. Both aspects of writing are important in the typical language class, and both can serve to reinforce the other (Kenneth Chastain: 1988, 244 ).

4. It is an active means of communicating ideas. 
5. It is also a major classroom procedure involving dictation, comprehension, summary, written exercises, etc.

6. It is an important skill that must be developed at the early stage of learning.

7. It requires the following (1) Knowledge of alphabet system. (2) The relationship between sounds and the written symbols (or thography). (3) Knowledge of mechanic of writing (spelling, capitalization, punctuation, etc.). (4) Control of basic sentence structure. (5) Familiarity with grammar and lexical. (6) Skill in combing sentences.

8. In spite of the different approach used, the ultimate purpose behind teaching writing is grasping by the reader and to send message from the writer to the reader throughout dictation, composition and so on. 


\section{Bibliography:}

1. Al - Hamash , Khalil . (1980) . Principles and Techniques . Iraq : ALRISSAFI PRINTING PRESS .

2. Crystal, David .( 2003 ) . The Cambridge Encyclopedia of the English Language . $\left(2^{\text {nd }}\right.$ ed $)$. Cambridge : Cambridge University Press .

3. Harmar , Jeremy . ( 2009 ). The Practice of English Language Teaching $.4^{\text {th }}$ ed . USA : Pearson Longman.

4. Hartmann \& Stork .( 1972 ). Dictionary of Language and Linguistics . London : Applied Science Publishers LTD.

5. Nunan, Davia . ( 2003 ) . Practical English Language Teaching . USA : Mc . Graw- Hill Companies, Inc .

6. Nunan, David \& Carter, Ronald . ( 2001 ). The Cambridge Guide to Teaching English to Speakers of other Languages . Cambridge : Cambridge University Press .

7. Nunan, David . ( ND ). Second Language Teaching \& Learning . USA . 8. Rao , Venugopal . ( 2003 ) . Methods of Teaching English . NEELK AMAL PUBLICATIONS PVT . LTD .

9. Rivers, Wilga M . ( 1981 ). Teaching Foreign Language Skills . $2^{\text {nd }}$ ed . USA : The University of Chicago Press .

10. Venkateswaran , S . ( 1995 ). Principles of Teaching English . Publishing House PVT LTD . 